\title{
Qohelet as an Expression of Old Testament "Pastoral Care" of the Rich
}

\author{
Adam Mackerle
}

The Old Testament deals with the issue of riches and poverty extensively. The reader will recall the repeated sharp pronouncements of the prophets against abuse of riches and power against the weaker and the poorer, the legal as well as moral protection of "strangers, orphans and widows", and others.' Nonetheless, property and related issues are a much broader topic than just an occasion to criticism and distrust of the rich. The issue of riches in the Bible is discussed e.g. in the book L'argent dans la Bible. ${ }^{2}$ Its author concisely points out the equivocal relationship of the human being to property and the ambiguous place and function of property in relationships among humans and to God.

Of the colourful mosaic of ways the Old Testament evaluates property and human relationship to it, this study focuses on "pastoral care" of the rich. It does so primarily because the contemporary reader is acquainted primarily with the way Biblical texts care for the poor and the marginalized and rarely gets an opportunity to realize that the fundamental evaluation of property and riches in Old as well as New Testament is essentially positive.

I have chosen Qohelet for the topic of "pastoral care of the rich" not because it speaks of riches (and poverty), but because it speaks to the rich and strives to help them find happiness in their riches. From a certain perspective the rich and their riches may be taken to be the focus of Qohelet's care (and this study is an explication of this claim). Apart from Qohelet there is one other book in the Old Testament dealing with a similar topic but aimed rather at an opposite group of recipients. It is the book of Job which reflects the drama of unfair and undeserved suffering and in that context asks about the meaning of life in such conditions. The book of Job addresses the issue of meaning of life "from below", i.e. from the position of one who has lost all he had and has nothing but pain and worry left. The book of Qohelet deals with the same issue of meaning of life "from above", since the author presents himself as the rich and powerful person of Solomon, king of Jerusalem. The two books could be called an expression of Old Testament "pastoral care" of the poor and the rich. Both Qohelet and Job are portrayed as extreme instances of human wealth and saturation of all desires on the one hand (Qohelet), and humanly unfathomable extreme suffering and loss of everything on the other. Just as Job seeks the meaning of life permeated by suffering, so Qohelet seeks meaning, though in a diametrically different life situation. Job has nothing, Qohelet has everything. And yet both are haunted by the same question: what is the meaning of all that (as Qohelet says) is done under the sun, and how is one to relate to it? Both books set out from radicalized, acute situations, intentionally depicted in extreme terms, and together provide two opposing perspectives of human life and its meaning. "The arguments of Job and Ecclesiastes provide complementary perspectives on the powerful dynamics of disillusionment in adversity and the corresponding challenges

\footnotetext{
1 Especially the prophetic books of Hosea, Amos, Micah and Zephaniah, as well as other texts, e.g. Old Testament law codes in the Pentateuch (esp. Deuteronomy), where the phrase "foreigners, orphans, widows" frequently appears.

2 Cf. P. DEBERGÉ, L'argent dans la Bible, Montrouge: Nouvelle Cité, «Racines», 1999.
} 
of providing them to relinquish self-sufficiency and instead to seek life from God and listen to his voice. ... They serve as literary exemplars of self-sufficient righteousness and wisdom, respectively". ${ }^{3}$ That is the point of view from which we will focus on the book of Qohelet now.

\section{Qohelet the Philosopher}

Concisely describing and grasping the character of a book is always a demanding task and in case of the book of Qohelet we are no better off. Nonetheless, we will attempt to sketch the basic outlines of Qohelet's work. The book of Qohelet is probably the most philosophical book of the Old Testament, in a number of respects. First of all, it is the rational reflection of the author (let us call him conventionally Qohelet), deriving from his everyday experience. ${ }^{4}$ Qohelet does not develop his consideration systematically from premises through partial conclusions to final ones, but formulates it in a mosaic of short reflections, sometimes rather like aphorisms. ${ }^{5}$ In that it is similar to e.g. Epictetus' Enchiridion or his Discourses or the Meditations of Marcus Aurelius. There are over fourty such individual longer and shorter pieces in the book; the exact number is hard to state, since identifying the dividing line between the individual passages is in many cases difficult. Qohelet begins many of these short "aphorisms" with verbs in the first person intended to underline that the following reflection derives from his own personal observation.

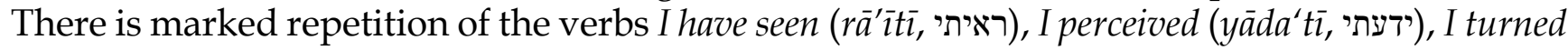

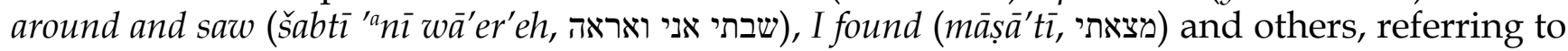
personal experience which becomes the source of reflection. There are other indices of personal experience and rational reflection deriving from it - the frequently repeated word meaning mind (literally "heart", lēb, לב ), which Qohelet devotes (verb $n t n$, נתן) to an activity and to which he speaks (verb $d b r$, דבר, (אמר, or 'mr), autobiographical stylization and others.

The author's decision to proceed rationally and logically is also reflected in his choice to refrain from all arguments not based on experience or reason. While Old Testament books normally do not speak of afterlife, the book of Qohelet is one of the few which explicitly refuse to take it into consideration: For humans and beasts have one fate - as the ones die, so die the others, and in all there is one spirit. A human has no advantage over the beasts, for all is vanity. All goes to one place; all comes from the dust, and to dust all returns. Who knows whether the spirit of a human goes upward and the spirit of the beast goes down to the earth? (3:19-21). It is not a fundamental denial of the possibility of afterlife, but a methodological expression of the view that the existence of afterlife is indemonstrable. That is why Qohelet refuses to take it into account when reflecting on the nature of human life. For him, afterlife is not a logical, rational argument. ${ }^{6}$

3 J. S. REITMAN, “God's 'Eye' for the Imago Dei: Wise Advocacy amid Disillusionment in Job and Ecclesiastes”, Trinity Journal, 31 (2010), p. 117.

4 M. GILBERT, La Sapienza del cielo, Milano: San Paolo, 2005, p. 113 describes Qohelet as "a scholar in the sense contemporary university world ascribes to the word". With respect to the way religion influences his reflection he calls him "more philosophical than theological" (ibid., p. 114). Many studies deal with the relationship of Qohelet to contemporary philosophy and possible direct and indirect influences. For an illuminative description of how Qohelet is intertwined with philosophical topics and contemporary philosophy see the commentary of V. ZAPLETAL, Das Buch Kohelet kritisch und metrisch untersucht, übersetzt und erklärt, Freiburg im Breisgau: Herdersche Verlagshandlung, 1911, where to every Qohelet idea the author assigns parallels from contemporary philosophical works. The abundance of quotations accompanying almost every passage of the Qohelet unambiguously points to the philosophical character of the work.

5 I am aware of the fact that there is no consensus concerning the structure of the book Qohelet. "As far as the overall structure of the book is concerned, we must admit our own ignorance. It is sufficient to simply compare the various and most common contemporary translations to understand the hesitance of exegetes to make a statement on the problem" (M. GILBERT, La Sapienza..., p. 108). The claim is based on the fact that "no attempt at literary analysis seems to be sufficiently capable of proving the existence of an overall structure of the text" (L. MAZZINGHI, Ho cercato e ho esplorato. Studi su Qohelet. Bologna: EDB, 2001, p. 47) and also on macro-syntactic signals in the text, which are the repeated expression "I saw", "I said in my heart" and others, which structure the text in many discrete reflections (see below). For a similar division cf. V. ZAPLETAL, Das Buch Kohelet.

6 L. MAZZINGHI, Ho cercato..., pp. 73-74 and again at pp. 183-186 contrasts Qohelet on the issue of the possibility of human cognition and 
The philosophical character of the book is uncontested by the fact that the author frequently uses the word god. The word is not prohibited in philosophy, and if we were to exclude as nonphilosophical all texts speaking of god or gods, we would find that there is virtually no ancient philosophical writing. Just as e.g. for the Stoics, so also for Qohelet the god of whom he speaks is not the god of the Israeli nation, to whom he has revealed himself and whom he had chosen, but the creator god, god supervising the functioning of the world, the source of all being, whose design is wise, though not always comprehensible to a human. Qohelet consistently uses only one designation for god, the general term ' ${ }^{\prime}$ lohim (אלהים), ${ }^{7}$ never his name YHWH (יהוה) or another term denoting the particular God of Israel. Seneca and Epictetus ${ }^{8}$ often speak of god or gods (dei, $\theta \varepsilon o i$ ) or of providence (providentia, $\pi \rho o v o i a)$ in similar context. That is why I write god with lower-case "g", in order to highlight this general characteristic of "deity", not necessarily connected with the God of Israel, although even in this book god is a provider. The just outlined image of god is typical of sapiential literature, especially (besides Qohelet) the Old Testament books of Proverbs and Job. ${ }^{9}$ Unlike afterlife, Qohelet takes the existence of (this) god for granted as something that need not be demonstrated, because it is part of the nature of the world and is evident from it. For a rounded view let me add that such image of god does not contradict the way God of Israel is conceived in other, especially historical and prophetic books, but is one of his aspects by which he manifests himself and makes himself known.

\section{Qohelet's Question.}

If Qohelet is a "philosophical enquirer", what is the main question he asks and seeks to answer? It is the question of the meaning of all human activity and human existence as such. Insofar as Qohelet formulates the question of meaning as the question of happiness and possibility of its realization, one can say that "in the centre of the book Qohelet there is the question about the content and condition of possibility of human happiness" ${ }^{10}$ The author formulates his question several times in the course of the book, especially in the introductory reflections. The first and perhaps the most poignant formulation can be found at the very beginning (1:3): What does a human gain by all the toil at which he toils under the sun? In further modifications it says: Where is good found for humans to do under the sun during the time of their life? (2:3); What has a human from all the toil and striving of mind with which he toils under the sun? (2:22); and finally: What gain has the worker from his toil? (3:9). The key terms for Qohelet are frenetic human toil ('āmāl, עמ) on the one hand, and possible gain (yitrōn, יתרון) expected of it on the other. ${ }^{11}$ Toil does not stand for individual human activities, it rather comprises all labour and effort characteristic of human life. Rather than of toil one could speak of the effort of man that everything he does and lives for has some meaning and endurance, some absolute and permanent value. ${ }^{12}$ This to a certain

\footnotetext{
hopes with the apocalyptic, particularly henochism, emerging at probably the same time Qohelet was written. In contrast to the apocalyptic quest to grasp and understand the mystery of history and time and nurture hope in eschatological events, Qohelet's attitude may appear as rational agnosticism.

7 The term sometimes appears with the definite article, though apparently with no change of meaning.

8 Especially Seneca's dialogue De brevitate vitae, thematically very close to Qohelet, and Epictetus' Discourses or Enchiridion.

9 L. MAZZINGHI, Ho cercato..., p. 413 concisely enumerates further elements distinguishing the book Qohelet from mainstream Israeli Old Testament tradition: Qohelet only uses the term 'elohim; he never refers to events of Israeli history, such as the exodus, desert wandering, Sinai and occupation of the promised land; there is no God of retribution who rewards the bad and the good according to their deeds; there are no terms pertaining to salvation or love; the author never addresses God, merely speaks "of" him; there is no reference to cult (except 4:17-5:6). 10 L. SCHWIENHORST-SCHÖNBERGER. Kohelet. Freiburg: Herder, 2004, p. 70.

11 The term yitrōn (יתרון) denotes "surplus", the recoverability of an activity in which effort and capital has been invested. Qohelet uses this "economic" term in a more general sense, or in other words he explores human existence in economic terms. The opposite (and similarly economic) term of Qohelet's is lack, deficiency (חסרון, hesrōn, 1:15). Cf. T. KRONHOLM, "', in Theologisches Wörterbuch zum Alten Testament, vol. 3, col. 1087.

12 In the context of the book's origin (probably the time of the Hellenistic kingdoms in 3rd to 1st century B.C.) the author may be implying that God relates to man in a similar fashion as his (Ptolemaic?) rulers, who required him to work hard without being able to enjoy the fruits
} 
extent transcendent aspect of the question is determined by the one who asks. If it is someone who has attained success in everything he has attempted, then the question transcends the material, mundane sense. The toil of this person has attained the primary aim - property, material security, wisdom and others - but there nonetheless remains a certain nonfulfillment and emptiness.

Qohelet's quest is to a large extent systematic. He addresses various activities in which humans frequently seek happiness and meaning and asks to what extent these activities really carry meaning and make humans happy. He focuses on accumulating property, enjoying food, drink, merriment and other enjoyments, industrious construction, acquiring wisdom, gaining fame and renown, and many others. When Qohelet himself experiences and subsequently reflects on each of these options, he reaches a strict and firmly determined limit that a human will never be able to cross. The limit appears under several aspects. ${ }^{13}$

The author starts with everyday things with which he attempts to fill the emptiness he experiences in life. I said in my heart, Come now, I will test you with pleasure; enjoy yourself. (2:1). Then he describes all he did and achieved, and his words sound like a description of what many dream of: I made great works. I built houses and planted vineyards for myself. I made myself gardens and parks, and planted in them all kinds of fruit trees. I made myself pools from which to water parks full of growing trees. I bought male and female slaves, and I had abundance of house servants, and also great amounts of sheep and cattle, more than all who had been before me in Jerusalem. I was great and gathered for myself silver and gold and the treasure of kings and provinces. I got singers, both men and women, and the luxury of men as well as many concubines. So I was greater and gathered more than all who were before me in Jerusalem. And I also had wisdom. And whatever my eyes desired I did not keep from them. I kept myself from no pleasure... (2:4-10). And yet he eventually describes all the gain he had from it as vanity and a striving after wind (2:11). In this text Qohelet questions the sense of pursuing and cumulating enjoyments, as if the degree of one's happiness were directly proportionate to the number of sensual enjoyments.

At other times Qohelet finds the limitation of human beings in their incapacity to knowledge. However much a human enquires, his knowledge will never encompass everything, not even a fragment of all there is to know: a human will not comprehend the work god has done, from the beginning to the end (3:11); a human cannot discover the work that is done under the sun (8:17). Human knowledge will necessarily always remain limited, fragmentary and partial. In fact, one will not understand anything of the world surrounding him. Human incapacity to complete knowledge and understanding of what takes place under the sun does not reflect only a rational incapacity. The author also encounters the absurdity of what takes place under the sun; nothing is as it should be and human reason cannot grasp it. When one wants to really understand the chaotic, meaningless world, reason lets him down. Insofar as god is the author of this world, he is also responsible for its incomprehensibility. On the other hand, what man is capable of acquiring is unpleasant and does not bring happiness, so that in much wisdom there is much vexation, and he who increases knowledge increases sorrow (1:18). In fact, one only discovers his knowledge of the chaotic and absurd nature of the world. The advantage of wisdom over

of his work. This socio-economic situation markedly affected Qohelet's perception and valuation of life. Cf. D. RUDMAN, Determinism in the Book of Ecclesiastes. Sheffield: Sheffield Academic Press, 2001, p. 22; cf. also L. MAZZINGHI, Ho cercato..., pp. 423-424 and the analysis of the socio-economic context of the book in Ch.-L. SEOW, Ecclesiastes, Doubleday 1997, pp. 21-36. Nonetheless, the scope of what Qohelet says is much more universal and general.

13 B. L. BERGER, "Qohelet and the Exigences of the Absurd", in Biblical Interpretation 2/9 (2001), pp. 141-179 speaks at pp. 144-154 of four topics Qohelet repeatedly returns to while describing the absurdity of human existence, which correspond to the following: toil the fruits of which are enjoyed by another, non-existence of memory of the person and eternal oblivion, non-existence of justice in the world, and the fact that wisdom does not help man escape the absurdity of life. 
folly is merely relative, since though the wise walks in light and the fool in darkness, the same event happens to all of them and the wise dies just like the fool (2:14.16). Wisdom cannot provide an answer to the most important question of the meaning of the world and human life.

Just as a human never really penetrates anything with his reason, he will never be able to change anything for the better. What is crooked cannot be made straight, and what is lacking cannot be counted (1:15), and the injustice of the world - which there always has been and ever will be - cannot be eradicated. Qohelet does not hesitate to let the reader see that he knows of all the injustice occurring in the world: the swift have nowhere to run, warriors have no battle to fight, the wise have no bread, those who understand things have no riches, those with knowledge are not in favour, because time and chance happen to them all (9:11); and there is an error proceeding from the ruler: the fool sits in a very high place, while the rich sit in a low place. I have seen slaves on horses, and princes walking on the ground like slaves (10:5-7). Qohelet even expresses certain fatalism when he says that whatever god does endures forever; nothing can be added to it, nor anything taken from it (3:14). And in yet other words: who can make straight what he (i.e., god) has made crooked? (7:13). As with the incomprehensibility of the world, the creator is also directly responsible for injustice and the texts repeatedly recall this.

A human will never be able to transcend himself and will never "make it big", since there is nothing genuinely new and unforeseen. What has been is what will be, and what has been done is what will be done. There is nothing new under the sun. Is there a thing of which it is said, "See, this is new"? It has been already in the ages before us. There is no remembrance of former things, and there will be no remembrance of later things yet to be among those who come after (1:9-11). These words appear in Qohelet's very first reflection, foreboding the entire book and reminding the reader that our derangement and false hope in change and something new is largely due to the weakness of human memory. Because of its frailty and forgetting, there is no point striving to accomplish heroic deeds in order to "inscribe oneself in history". Qohelet gives the example of a wise boy who attained the royal throne and became very famous, and yet there was no end to the human multitude before them and those who come later will not rejoice in him (4:16).

A human is hopelessly enclosed in the time between his birth and death and cannot free himself from it in any way. When he dies his name and fame will pass away and disappear. One can learn from the previous generations - who remembers the generations of humans who came before us? What do we know of them? What they lived for has gone, their love and their hate and their envy have already perished, and forever they have no more share in all that is done under the sun (9:6). The same fate awaits humans alive today, as well as those yet to come.

A human cannot anticipate or know what will happen when he dies. Qohelet even claims that god intentionally arranged it so: When the day is good, enjoy it, when the day is adverse, consider this: god has made the one as well as the other, so that man may not find out anything that will be after him (7:14). That is also why it is pointless to work for one's posterity and deny oneself prosperity for their future happiness. I came to hate all my toil in which I toil under the sun, seeing that I must leave it to the one who will come after me. Who knows whether he will be wise or a fool? He will take hold of all my toil, in which I toiled wisely under the sun (2:18-19). Therefore this is not a way to break through the limitations posed by human impermanence and finitude, either.

All the limits a human being encounters during his lifetime have a common source - god himself. The limitations imposed on human beings are not an accidental consequence of the world against which one may appeal to god, but god's intentional act. According to Qohelet, god limits humans knowingly and intentionally. A possible reason for such divine acting may 
be god's effort to direct humans towards the only appropriate attitude to life which Qohelet reaches through his reflection, to be discussed soon.

Qohelet's reflections on property and material riches also take place in the context of thus perceived limits and limitations of human life. For Qohelet, property is always a result of work or toil ('âmāl, עמל). Qohelet does not address the problem of one who has undeservedly gained wealth and asks what to do with it. Qohelet asks about the sense of diligent human work which brings fruit. His question does not primarily concern property as such, but the meaning of human activity leading up to it, whose aim is to acquire property. If he asks about the sense of material property, it is only because he wants to know whether property acquired by toilsome work can provide sufficient meaning to human activity and human life in general: Is it worthwhile to devote your life to acquiring property? Or in Exupéry's words: Does it make sense to exchange your life for accumulating property $?^{14}$ Let us immediately add that the author's answer is definitely not an immediate "no", as if it were an easy question with a banal answer. The author is aware that if he said that "no", he would then have to offer the reader something else, more important than property and worthy of being exchanged for human life - and the search for something like that is the essence of Qohelet's book and Qohelet does not reach a univocal answer. The question thus appears much more difficult than it had seemed at first glance.

Among passages focusing most closely on material property, the section 5:10-20 stands out. From the very beginning Qohelet states the paradox of property: He who loves money will not be satisfied with money, he who loves abundance will not get an income. However, the problem of property does not consist in property itself, but in human relationship to it. Qohelet's remark is short, pragmatic and throughout practical. He does not claim that love of riches draws one away from some other good, as if he enviously wanted to deny the rich enjoyment of property. He quite concretely and pragmatically states that overt attachment to and love of property is counterproductive in its very own sphere - a human will not be satisfied with it. In other words, if property becomes a value in itself, it will not make a human happy. If therefore someone wants to enjoy his fortune, he must not love it. The following remark is similar: When goods multiply, there also multiply those who eat them. What advantage has their owner but that he can

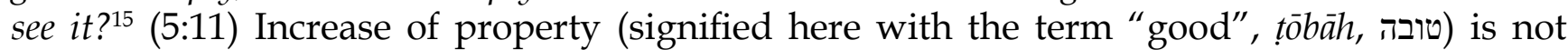
necessarily connected with increased gain from it, since there will always be those who sponge on it. The owner cannot but watch. Both statements warn against overt expectations placed on acquired property and the following one has a similar cling: The sleep of a worker ${ }^{16}$ is pleasant whether he eats little or much, but the satiation of the rich will not let him sleep (5:12). For it is paradoxically not property, what one owns, what makes one happy. Here the measure of happiness is content (literally "sweet", $m^{e} t \bar{u} q \bar{a} h$, מתוקה) sleep. Its "sweetness" depends on one's work, not on what one owns. Quite on the contrary, if it does depend on property in some way, then the dependence is indirectly proportionate: satiation, the desired and yearned for product and gain of property, brings dissatisfaction along. With these short aphorisms Qohelet calls

14 Cf. A. DE SAINT EXUPÉRY, The Wisdom of the Sands, e.g. 6:13 and elsewhere. Exupéry frequently uses the phrase exchange (one's) life for (échanger [sa] vie contre) or exchange oneself for (s'échanger contre).

15 Translating this phrase is prone to ambiguity. At several places $(2: 1 ; 3: 13 ; 5: 17 ; 6: 6.9 ; 9: 9)$ Qohelet uses the verb look (rá'áh, האר $)$ in the sense of enjoy something (a good [טוב, tōb], life [חיים, hayyim]) and it may carry the same meaning here. The translation would then be: What (other) use is it to its owner than that he enjoys it?

16 Precise identification of the "worker" (העבד, ha'ōbèd) is difficult and uncertain. The verb may mean "work", but also (as it is common in Biblical Hebrew) "serve". Its meaning does not consist in the contrast of "lord" and "servant", and apparently not in the contrast of "work" and "idleness" either (since even the rich man toils), but in overt anxiousness which gives the rich man no rest, while the "ordinary" worker or servant/slave has no worry of this kind and can sleep soundly after work. Cf. Ch.-L. SEOW, Ecclesiastes, pp. 205-206. Cf. also M. V. FOX, Qohelet And His Contradictions. Sheffield: The Almond Press, 1989, pp. 214-215. 
attention to the fact that property does not by far meet the expectations humans place on it. And so after a short reflection of the impossibility to take one's property away from life, Qohelet again returns to his old reiterated claim that the good that is worthwhile is to eat and drink and find enjoyment in all the toil with which one toils... (5:17).

The above also implies Qohelet's evaluation of human work that leads or can lead to acquisition of property. Qohelet deems human work to be necessary and good - it is just this effort what brings fruits and enjoyment of them, not just accumulated property. He who observes the wind will not sow, and he who regards the clouds will not reap. As you do not know the way of the wind or the bones in the womb of a pregnant woman, so you do not know the work of god who makes everything. In the morning sow your seed, and until evening do not let your hands rest, for you do not know which is appropriate, this or that, or whether both alike will be good (11:4-6). Qohelet underlines that it is not good to philosophize and ponder much rather than work, since only genuine and concrete work brings fruit.

The main and most important limitation determining a human, of which the preceding are but changeable appearances, is death. Qohelet reminds the reader of it in various ways. Once by speaking of those who came before him and those who will come after him. Thus he reminds the reader that human existence on this earth is contingent, leaving no permanent mark. At other times Qohelet speaks of the time of his life (literally of the days of [his] life, yeme hayyim, ימי חיים , in order to remind him that there is a definite, limited number of the days of his life and he can only toil under the sun while they last. And what is just as important, only in these days can he reap the fruits of his toil and enjoy them. It is therefore of prime importance to consider what the toil of these days is devoted to. Death means oblivion, especially falling into oblivion among those who will come after us. The value and meaning of human life cannot consist in what has remained of him up to the present, since nothing has. It must be found here and now, within this life, since this life is valuable in itself, regardless of the possible (non) existence of afterlife. ${ }^{17}$

By constantly returning to the theme of death Qohelet as it were keeps repeating the well-known saying memento mori - "remember death". The theme of death is also what Qohelet concludes his reflections with. The last one (before the two epilogues at 12:9-11 and 12:12-14) describes in detail human aging and death (11:7-12:8). Scholars disagree over the precise character of the text, whether it is an allegory, a description, or something else. ${ }^{18}$ The poetic ending of this passage culminates in the main thesis of the book, found also at its very beginning: (remember your creator) before the silver cord is snapped, or the golden bowl is broken, or the pitcher is shattered at the fountain, or the wheel broken at the cistern, and the dust returns to the earth it was before, and the spirit returns to god who gave it. Vanity of vanities, says Qohelet; all is vanity (12:6-8). The author links the constant thought of death with thought of the creator, i.e., respect towards him.

Human limitation is regularly expressed with the phrase under the sun (tahat haššemeš, (תחת השמש). The sun is the horizon beyond which a human will never get. By its everyday course the sun delimits a human's earthly life and reminds him of his finitude and the contingency

17 Cf. L. SCHWIENHORST-SCHÖNBERGER, Kohelet, p. 79.

18 Besides various commentaries cf. especially the paper by M. V. FOX, "Aging and Death in Qohelet 12", Journal for the Study of the Old Testament, 42 (1988), pp. 55-77, where the author presents three main lines of interpretation: literal, symbolic and allegorical. 
of his existence. ${ }^{19}$ The sun "represents a limit, a frame, the setting out of possibilities".$^{20}$ This limit set for humans is the reason why Qohelet repeatedly declares of various human activities: And also that is vanity and a striving after wind. Vanity (hebel, הבל), toiling for wind ${ }^{21}$ (ra'yōn rü $\bar{u}^{a} h$, רעיון רוח), striving after wind ( $r^{\prime} \bar{u} t r \bar{u} a h$, רעות רוח), and evil occupation ('inyan $r \bar{r}^{\prime}$, ענין) are typical expressions Qohelet uses to describe all human activity. Especially hebel (הבל) is a generally known concept of the book and is translated in various ways. Most Czech translations retain the traditional term vanity, they rarely choose other options such as impermanence or nothing. ${ }^{22}$ The original meaning is breath or vapour, haze, something impermanent and unseizable, something of no value. ${ }^{23}$ For Qohelet the term summarizes the nature of all existence and may also be translated "absurd", "meaningless". ${ }^{24}$

Qohelet can thus reach a fairly radical claim, bewildering and unpleasant to a contemporary (especially Christian and ethically educated) reader, expressed in chapter 3 (3:1-9):

For everything there is a season, and a time for every matter under heaven:

a time to be born, and a time to die;

a time to plant, and a time to pluck up what is planted;

a time to kill, and a time to heal;

a time to break down, and a time to build up;

a time to weep, and a time to laugh;

a time to mourn, and a time to dance;

a time to cast away stones, and a time to gather stones together;

a time to embrace, and a time to refrain from embracing;

a time to seek, and a time to lose;

a time to keep, and a time to cast away;

a time to tear, and a time to sew;

a time to keep silence, and a time to speak;

a time to love, and a time to hate;

a time for war, and a time for peace.

What gain has the worker from his toil?

Here Qohelet is proclaiming absolute relativity of human activity. Of what a human can do, nothing is of absolute value, nothing is good at all times and in all places, for no activity it holds that "there is always time for it". The value of an activity always depends on circumstances and on the specific situation, it is always subordinate to the present moment. To claim that an activity is good and proper at all times, in all places, and under all circumstances is an

19 Further connotations may be supplemented: the sun (šemeš, שמש) distinguishes the life of mortal humans (under the sun) from the life of immortal gods (with the sun); the preposition under (tahat, תחת) evokes the idea of subordination and servitude, and others. Cf. J. G. JANZEN, "Qohelet on Life 'Under the Sun'”, The Catholic Biblical Quarterly, 70 (2008), pp. 470-471.

20 K. FLOSSMANN, Moudrost ve Starém zákoně. Praha: Česká katolická charita, 1989, p. 149.

21 The phrase appears in two places (1:17 and 4:16) and in parallel to toil of the mind (literally heart, לביון (ra'yōn lēb, see 2:22) it can also be translated as toil of the (human) spirit. That is how Jerome translates it (adflictio spiritus), as well as the Kralice Bible (trápeni ducha), King James' Bible (vexation of spirit) and others.

22 There is surpirising uniformity in Czech translations in translating the term hebel. Virtually all translations render the word with the equivalent "marnost" ("vanity"). Exceptions are the Czech Ecumenical Translation ("pomíjivost", "transient; something, that passes by") and Viktor Fischl's translation ("nic", "nothing"; see Poezie Starého zákona, Praha: Garamond, 2002).

23 Apart from the book Qohelet, Old Testament uses the term (not mentioning its use as the proper name of Abel) especially 1) to express that something has no value and perishes (especially human life and the human being); 2) to wail; 3) to denote foreign gods in order to highlight their unreliability. Cf. K. SEYBOLD, "הבל", in Theologisches Wörterbuch zum Alten Testament, vol. 2, cols. 337-340. There is extensive discussion of the term and its interpretation. Cf. especially N. LOHFINK. "Koh 1,2 'alles ist Windhauch' - universale oder anthropologische Aussage?" in IDEM, Studien zu Kohelet. Stuttgart: Katholisches Bibelwerk, 1998, pp. 125-142; IDEM, “Zu הבל im Buch Kohelet”, ibid., pp. 215-258.

24 Cf. E. TAMEZ, "Ecclesiastes. A Reading from the Periphery", Interpretation, 3/2001, p. 251. The author points out that there are more expressive terms in everyday speech such as "garbage" or "shit". 
absolutization. By that the activity would transcend the limitation of the contingence of human existence and provide meaning and firm ground for human life. However, there is no such activity according to Qohelet. If a human wants to transcend himself and his impermanence and set himself on an activity, he can do so, but it will bring him disappointment, since no activity will in fact grant that. That is why at the end of this "litany of activities" Qohelet again raises his fundamental question: What gain has the one who does something from his toil? Similar, even scandalous relativity sounds again a little further: Be not overly righteous, and be not wiser than necessary - why should you destroy yourself? Be not overly wicked and do not be a fool - why should you die before your time? (7:16-17).

In a certain sense Qohelet can really be called a nihilist. If we accept the definition of nihilism, as offered e.g. by Nietzsche, i.e., "Nihilism: the aim is lacking; 'why' finds no answer. What does nihilism mean? That the highest values devaluate themselves", ${ }^{25}$ then Qohelet really falls in this category by the question he asks and his analysis of the human situation. However, if we do not stop at Qohelet's nihilist question and consider also his response, we find that the author withdraws himself from nihilism. ${ }^{26}$ If we wanted to classify the author under a philosophical school, existentialism seems the most appropriate to me. ${ }^{27}$

When I claim that one can speak of the book of Qohelet as of an expression of Old Testament pastoral care of the rich, it is precisely because of this essentially existential question the author asks and because of the detailed analysis of the human life situation. What question is that? Whoever the real author of the book was, in the text he presents himself as King Solomon. ${ }^{28}$ This is apparent from the very title of the book (The words of Qohelet, the son of David, king in Jerusalem [1:1]; I Qohelet have been king over Israel in Jerusalem [1:12]), as well as from the way he introduces and speaks of himself. What he underlines is his fortune and power. Qohelet had all he desired and wished for at his disposal and could accomplish all that a human can. Just as Job is an image of a suffering human, in whom all human suffering and pain is concentrated, so Qohelet is the opposite, he is the "concentration" of all a human can desire: I increased and multiplied wisdom more than all who were in Jerusalem before me (1:16). Elsewhere, after an extensive enumeration of all he has accomplished and gained, he says: I acquired more than all who were before me in Jerusalem and I also had wisdom. I did not keep from my eyes anything they desired. I refrained from no pleasure... (2:9-10).

In this sense Qohelet is a faithful representation of the contemporary European who suffers of no primary urgent need in the sense of not being certain whether he will have enough to eat tomorrow and whether he will still be alive. Qohelet represents a situation of extreme riches and fortune. That functions as a lense through which we view the contemporary human. Qohelet is someone who can have surplus and asks whether there is true happiness to be found in such surplus - whether it consists in property, power, enjoyments, study, or anything else -, or, what

25 F. W. NIETZSCHE, The Will To Power. New York: Random House, 1968, p. 9, note 1.

26 The nihilist aspect of the book Qohelet is the focus of S. SEKINE, "Qohelet als Nihilist", Annual of Japanese Biblical Institute, 17 (1991), pp. 3-54. However, the author only deals with one aspect of Qohelet's statement, i.e., his original perception of reality. The analysis and correspondence of its results to nihilism is precise, but the author does not engage with Qohelet's response and his calls to joy and respect of God (see below) and the fact that the author employs relativism to point out where true values are to be found and where they are not. Cf. L. SCHWIENHORST-SCHÖNBERGER, Kohelet, p. 89.

27 Qohelet is frequently compared to Albert Camus. Cf. e.g. B. L. BERGER, “Qohelet...", esp. pp. 164-176, where Qohelet is compared to Camus and Schestov. Often (not only in Berger) Camus' "Myth of Sisyphus" is quoted in connection with Qohelet, where Camus speaks of Sisyphus as of a tragic hero who heroically accepts his tragic fate of absurd, never to be fulfilled effort. As in the case of Nietzsche, Qohelet radically differs from Camus in his response.

28 Up until 1644 when Hugo Grotius suggested that the author may have been someone else from a later period, Solomon was assumed to be the real author of the book. Cf. L. MAZZINGHI, Ho cercato..., pp. 19-20. It is the book Hugonis Grotii Adnotationes ad Vetus Testamentum, vol. I, Paris 1644; cited passage at p. 521. 
is the gain (yitrōn, יתרון) of this surplus. Similarly, the secondary questions implied by the first one, i.e., questions about the meaning of the individual activities one engages in in his search for meaning, are also typical of such a human: surplus energy and resourses are employed for seeking and extending property, for care of one's reputation, for improving the world, for securing the well-being of one's posterity, for acquiring wisdom. All these questions are manifestations of the surplus Qohelet experiences, which enables and at the same time forces him to ask about human happiness. Flossmann therefore rightly speaks of Qohelet's "struggle with pseudo-ideas and pseudo-ideals" ${ }^{29}$

\section{The Answer}

If none of what has been enumerated above is the meaning of human life, what is? What activity is meaningful and makes one happy? Qohelet does provide an anwer and again, as his habit is, repeats it several times in his book. There is no good for a human than to eat and drink and afford himself good in his toil. (2:24); $;^{30}$ there is no other good than that a human should rejoice in his work (3:22); I have seen what good is worthwhile - to eat and drink and enjoy the good of all the toil with which one toils under the sun during the time of his life (5:18); there is nothing good for a human under the sun but to eat and drink and be joyful; this will accompany him in his toil all his life (8:15); and finally in the form of an exhortation: Go, eat your bread with joy, and drink your wine with a merry heart, for god has already approved what you do. Let your garments be always white. Let not oil be lacking on your head. Enjoy life with the woman you love, all the days of your vain life (9:7-9).

Qohelet's fundamental answer to the outlined human life situation is therefore "hedonism". For what is the use of what one gains - whether it is property, fame, wisdom or anything else - if one cannot enjoy it? If one is imprisoned between birth and death and cannot penetrate beyond those limits (or escape them), in other words, if all his life takes place under the sun and in contingency, in a world lacking apparent order and meaning, then happiness must also be sought here, under the sun, between birth and death, in what is given to humans. For Qohelet the only criterion is the joy stemming from enjoing the fruits of one's labour. Everything else leads astray, it is a temptation leading, if followed, only to frustration. If Qohelet belongs to wisdom literature, then his "wisdom" is to be able to stop and savour the joys of the moment. Happiness is for him "a specific manner of experience", ${ }^{31}$ where happiness does not arise from brief periods detached from the time of labour and toil, but is found directly in its mist. ${ }^{32}$

But there is a very important accompanying condition to Qohelet's "hedonism", which Qohelet never omits to emphasize. A condition the author insists on is permanent awareness that if there is something one can enjoy in his labour, if one has food and drink and a place to stay, and is able to enjoy it, then it is god's gift and it must elicit gratitude. For no work brings success and riches automatically, and even if one gains property, he need not be granted an opportunity to enjoy it. An attitude of gratefulness accompanying each moment, in which one enjoys the fruits of one's labour, therefore accompanies all the above mentioned statements: I saw that this also is from the hand of god (2:24); ... in the time of his life that god has given him, for this is his lot. Also that god has given a human riches and property and an opportunity to eat of them,

\footnotetext{
29 K. FLOSSMANN, Moudrost..., p. 145.

30 L. SWCHWIENHORST-SCHÖNBERGER, Kohelet, p. 76 translates differently: There is no good in man, when he eats, drinks and enjoys good in his toil. According to him the author's emphasis is not on what good consists in, but where it comes from; IT IS NOT FOUND in man, but in God whose gift it is. The translation relies on interpretation of prepositions.

31 L. SCHWIENHORST-SCHÖNBERGER, Kohelet, p. 78.

32 Cf. ibid., p. 81.
} 
and to accept his lot and rejoice in his toil - this also is a gift of god (5:18-19); ... all his life that god has given him under the sun (8:15); ... all the days of your vain life that god has given you under the sun, all the days of your vanity. For that is your lot in life and in your toil at which you toil under the sun (9:9). The author frequently uses the term lot (heleq, חלק), sometimes exclusively (e.g. in 3:22: since that is his lot). This concept also expresses the nature of human happiness as a gift, allotted by god..$^{33}$ Use of the verb give $(n t n$, נתן) where Qohelet says that god gives one the opportunity to use goods has similar meaning. In connection with the above described nature of human labour Mazzinghi can therefore justly say that "there are two sources of joy in Qohelet, it is the fruit of toilsome human work, and at the same time a gift of God". ${ }^{44}$ Joy can be separated neither from God who provides it, nor from human effort which leads up to it, although, as Qohelet underlines, joy is not a gain (yitrōn, יתרון) automatically derived from labour. ${ }^{35}$

If human life is signified by the shadow of death hovering over him throughout the time he lasts, and as a result by vanity and frustration, since nothing a human produces will last, will be permanent, this negative aspect is expressed by emphasizing respect to what transcends one and what he will never grasp. For what we call "respect" Hebrew usually uses the root $y r^{\prime}$ (ירא), i.e., "fear". But Qohelet, like authors of other Old Testament books, does not use this term to express fear of a strict god and uncertainty as to how he will behave to the human, but an attitude of respect to someone who transcends the human, to whom the human is responsible for his deeds, whom he takes seriously. To paraphrase Qohelet's words, it is a respect towards that which is "above the sun" and determines the course of this world. Qohelet admonishes to respect in other places as well and more openly, e.g. when he speaks of expressions of religious respect: Guard your steps when you go to god's temple... Be not rash with your mouth, let not your mind be hasty to utter a word before god, for god is in heaven and you are on earth - therefore let your words be few ... Do not delay paying what you have vowed to god, for he has no pleasure in fools; pay what you vow. It is better not to vow than vow and not pay. ... Respect god! (literally: fear god!) (5:1-7).

The epilogue of the book where the author summarizes his advice also belongs in this context. He finally exhorts to respect for god (i.e., "fear of God"): Respect god and keep his commandments, for this is all that is important for man. For god will bring every deed into judgment, when he judges all that is hidden (12:13-14). Here Qohelet recalls what he has spoken of before, i.e., the importance of respect for god, accepting one's limits and limitations and active accomplishment of one's place in life, one's "lot". The author implies that respect for god consists in keeping his commandments. He does not develop the theme further, as if he assumed that the reader knows well what he means. These words need not be interpreted as a "correction" of previous words, returning the book to the riverbed of orthodox Old Testament faith; the author rather reminds us that he has been in this riverbed all the time. ${ }^{36}$

In the book Qohelet god is described as one who on the one hand gives humans the opportunity

33 In Old Testament the term heleq (חלק) is most commonly used to refer to that, what "pertains to every individual human" (L. MAZZINGHI, Ho cercato..., p. 402). Mazzinghi (ibid.) contrasts in a certain sense gain (yitrōn, יתרון), and lot (heleq, since human effort leads to no gain, but there is lot in it.

34 L. MAZZINGHI, Ho cercato..., p. 404. The author elaborates on J. Y. S. PAHK, Il canto della gioia in Dio. L'itinerario sapienziale espresso dall'unità letteraria in Qohelet 8,16-9,10 e il parallelo di Ghilgamesh Me. III, Napoli 1996.

35 Cf. ibid., p. 405.

36 There is extensive discussion of the nature of the epilogue (12:9-14), whether it is part of the original text of a single author or an addition modifying the meaning of the book, an effort to make the book "more orthodox". An argument I find compelling is that it cannot be interpreted as setting the whole book in question, as if all that has been said should be placed in parentheses with a negative sign. Such editorial intervention would make no sense, since if the book is so heretical that it is necessary to radically change its content, then why correct it with one sentence and not discard it altogether? It is always better (as far as possible) to interpret a book (even if a number of authors collaborated on it) as an integral work, not divide it into the results of the work of different authors and interpret them separately. Further, the precepts (mișwōt, מצות, cf. 12:13) need not in the context of the book Qohelet necessarily refer to the Torah or the precepts revealed to Israel, but may be universally valid as some kind of "natural law". 
to enjoy the fruits of their work and to whom they should be grateful for it. At the same time god is the one who limits humans, who sets the limits to their life and knowledge. It is god who does not show humans what will come after them, it is god who does good and evil, who is the author of both the straight and the crooked in the world, which a human cannot straighten out. Respect for god thus equals respect for the limits a human perceives in his life, and therefore acceptance of the role, lot, assigned to him by god. "To fear God therefore means to accept that a human can never fully understand what God does in the world, and at the same time learn to accept as God's gift the simple joys of life granted to him" ${ }^{37}$ For Qohelet god is a concept negative and at the same time very positive. He remains hidden in order that humans, without comprehending, may respect his work and himself, and that they may respect mystery. As already mentioned, the book of Job has a similar outcome, when it ends with an exhortation to respect for the mystery of God's plan and intention that a human can never comprehend. ${ }^{38}$

The readers of the book of Qohelet may miss a number of topics which, according to their conviction, are related to property and life security, especially social responsibility and care of others. Qohelet only touches on the topic once, when he exhorts the reader: Cast your bread upon the waters, for you will find it again after many days. Give a portion to seven, or even to eight, for you know not what disaster may happen on earth... (11:1-2). The author does exhort to a certain compassion with others and almsgiving, but his reasoning is pragmatic, as it is in other parts of the book. Bread given to someone is not lost; it is bread deposited with another human which will "come back" in case of need. Care of the other is motivated by soundly egoistic reasons. There is no true (purely) altruistic attitude to the other in Qohelet, because the theme is not significant for the author's consideration. Similarly he does not address violence and willfulness, often associated with riches and acquiring them (as in the prophetic books mentioned at the beginning). The topics are important, but their place is on other pages of the Old Testament. Within the book Qohelet we can perceive them as encompassed by fear of god and in his commandments (cf. 12:13).

\section{Conclusion}

The message of the book of Qohelet and especially its evaluation of property and human effort directed towards reaching the stipulated goal, in order to secure fame, renown, riches, etc., could be summarized with an episode from the life of king Pyrrhus of Epirus, as the Greek philosopher Plutarch tells it in Pyrrhus's biography. ${ }^{39}$ When Pyrrhus was preparing for a military campaign into Italy against Rome, his friend and orator Kineas addressed him and asked him what he would do when - god grant - he conquers the Romans. Pyrrhus answered that he would occupy Italy. Kineas went on to ask what he would do afterwards. In Pyrrhus' words then would come Sicily, then Libya, or Carthage. Kineas' final question then was: When Pyrrhus had conquered everything that could be conquered, and when he had recaptured Macedon and Greece and there was no longer anyone whom he could fight, what would he do then? Pyrrhus' answer to the question was: "We will live at our ease, my dear friend, and drink all day, and divert ourselves with pleasant conversation." To that Kineas answered: "And what hinders us now, sir, if we have a mind to be merry, and entertain one another, since we have at hand without trouble all those necessary things, to which through much blood and great labour, and infinite hazards and mischief done to ourselves and to others, we

37 L. MAZZINGHI, Ho cercato..., p. 430.

38 Cf. especially the recent study of A. MACKERLE, "Suffering As A Path To Knowing God: On Interpreting The Book Job", Caritas et Veritas 1 (2012), pp. 27-38, esp. p. 37.

39 Cf. PLUTARCH, “Life of Pyrrhus”, 14, trans. John Dryden, at WWW: http://classics.mit.edu/Plutarch/pyrrhus.html. 
design at last to arrive?" Plutarch's Kineas like Qohelet reminds us that a human being often has true happiness at hand, and the only thing that prevents him from enjoying it and being happy is the human being himself with his foolish desire for something that in fact leads him away from happiness. Just as Plutarch's story, so the book of Qohelet facing an imperfect and incomprehensible world on the one hand fully appreciates and emphasizes the value of material happiness and enjoyments, but on the other hand also warns that finding happiness in the midst of material security is often very difficult, and that it is precisely material surplus what often leads a human away from true happiness, rather than provide it. Being happy is not an art only in the case of the poor and suffering, it is just as much an art for someone who has all that crosses his mind. True happiness thus does not consist in what a human has or how much he has, but in how he can deal with it within his life.

The Old Testament in the book of Qohelet accepts the possibility of wealth and does not condemn it. Quite on the contrary - it advises the rich on how to use what they have to be happy, with constant reference to god the provider, since riches and the opportunity to use them is a gift of god. Martin Luther in his commentary summarizes the message of the book of Qohelet in a similar way: "The meaning and advice of this book is therefore to instruct us that we use with gratitude the present things and God's creatures, abundantly given and granted to us of God's blessing, without worrying about what is to come; that we have a tranquil and quiet heart and a spirit full of joy, being content with God's word and deed." 40

\section{Qohelet as an Expression of Old Testament "Pastoral Care" of the Rich}

Abstract The paper presents the book of Qohelet as an example of Old Testament pastoral care of the rich. It starts with the main question the author addresses, which is the meaning of life and happiness. It then passes to various generally offered answers and rules them out as not satisfying. Finally, it provides an answer of its own. The paper views this questioning of human life and its meaning as an expression of Old Testament pastoral care of the rich, because the book is aimed at a rich audience whom it teaches how to find happiness and meaning in life.

Key words Bible, Old Testament, Ecclesiastes, Pastoral Care of the Rich, Wealth, Poverty 